\title{
Questionnaire about the impact of the pandemic on strabismus and amblyopia care in Latin America
}

\section{Cuestionario sobre el impacto de la pandemia en la atención del estrabismo y la ambliopía en Latinoamérica}

\author{
Silvia Moguel-Ancheita* \\ Mira Centro Oftalmológico, Mexico City, Mexico
}

\begin{abstract}
Objective: To identify the behavior and opinion of doctors dedicated to strabismus and amblyopia care regarding the impact of the COVID-19 pandemic. The concern about treatment delay in patients already diagnosed with strabismus and amblyopia, as well as the difficulty for the comprehensive study of new cases, has been the basis for the application of the questionnaire aimed at Latin American countries. Methods: A questionnaire of 11 items was prepared for physicians who attend strabismus and amblyopia cases from Latin American countries. The Google Drive platform was used, with the graphic elements under descriptive statistics and an exposure time from October 9-12, 2020. These results were partially reported during the webinar of the European Strabismological Association and International Strabismological Association: Impact of COVID-19 on strabismus management around the world, October 18, 2020. Results: We obtained 158 responses from 14 countries: Mexico 37\%, Argentina 19\%, Venezuela 14\%, Colombia 13\%, Peru 5\%, Chile 3\%, Ecuador 2\%, and Brazil, Paraguay, El Salvador, Bolivia, Costa Rica, Republic Dominican and Guatemala 1\%. Conclusions: The questionnaire on the impact of the COVID-19 pandemic demonstrates the concern of Latin American countries regarding the difficulty in monitoring patients with strabismus and amblyopia; but with greater severity in the new and silenced cases happening right now, and that the situations around confinement, economy, and difficulty of access to health services, can be compromising health in a dangerous way.
\end{abstract}

Key words: Strabismus. Pandemic. Amblyopia Nystagmus. Blindness. Impairment.

\section{Resumen}

Objetivo: Identificar la conducta y la opinión de los médicos dedicados al estrabismo y la ambliopía sobre el impacto de la pandemia de COVID-19. La preocupación por el retraso en el tratamiento de los pacientes ya diagnosticados de estrabismo y ambliopía, así como la dificultad para el estudio integral de los casos nuevos, han sido base para la aplicación del cuestionario dirigido a los países Latinoamericanos. Método: Se estableció un cuestionario de 11 preguntas dirigidas a médicos con atención a estrabismos y ambliopias, de países latinoamericanos. Se empleó la plataforma Google Drive, con los elementos gráficos bajo estadística descriptiva, y tiempo de exposición 9-12 de octubre de 2020. Estos resultados se reportaron parcialmente durante el webinar de la Asociación Europea de Estrabismo y la Asociación Internacional de Estrabismo: Impact of COVID-19 on strabismus management around the world, el 18 de octubre de 2020. Resultados: Se obtu-

\section{Correspondence:}

*Silvia Moguel-Ancheita

San Francisco, 1626-605

Col. Del Valle, Alc. Benito Juárez

Date of reception: 28-10-2020

Date of acceptance: 08-01-2021

C3100, Mexico City, Mexico

E-mail: smoguel@ prodigy.net.mx

2604-1731/๑ 2020 Sociedad Mexicana de Oftalmología. Published by Permanyer. This is an open access article under the CC BY-NC-ND license (http://creativecommons.org/licenses/by-nc-nd/4.0/).
Available online: 21-05-2021 Rev Mex Oftalmol (Eng). 2021;95(3):103-111

www.rmo.com.mx 
vieron 158 respuestas de 14 países: México 37\%, Argentina 19\%, Venezuela 14\%, Colombia 13\%, Perú 5\%, Chile 3\%, Ecuador 2\%, y Brasil, Paraguay, El Salvador, Bolivia, Costa Rica, República Dominicana y Guatemala 1\%. Conclusiones: El cuestionario sobre el impacto de la pandemia de COVID-19 demuestra la preocupación de los países Latinoamericanos ante la dificultad en el seguimiento de los pacientes con estrabismo y ambliopía, pero con mayor intensidad en los casos nuevos y silenciados que se pudieran estar presentando actualmente, y que las situaciones de encierro, economía y dificultad de acceso a los servicios de salud puedan estar comprometiendo de modo peligroso la vida.

Palabras clave: Estrabismo. Pandemia. Ambliopía. Nistagmo. Ceguera. Discapacidad.

\section{Introduction}

In December 2019, the disease caused by the severe acute respiratory syndrome coronavirus type 2 (SARSCoV2) called COVID-19, began in China, and it was declared a pandemic by the World Health Organization on March 11, $2020^{1}$.

Latin America was affected after the Asian and European countries. By October 9, 2020, there were 9,876,651 cases of COVID-19 registered in Latin America and the Caribbean, considering Brazil as the most affected country, with more than 5 million confirmed cases. Colombia ranked second, with around 886,000 infected, and Mexico registered a total of 804,488 cases, followed by Argentina, Peru, Chile and Ecuador ${ }^{2}$.

On March 18, the American Academy of Ophthalmology suggested to ophthalmologists the immediate cessation of non-urgent activities based on the recommendations of the American College of Surgeons, as well as strict hygienic measures and adequate control for face-to-face consultations, in addition to encouraging teleconsultation. The recommendations include using a questionnaire about risk history and exposure, maintain physical distance in the waiting room, limit the length of consultations, precautionary measures during slit-lamp examination, use of surgical masks, cleaning the areas after each patient and, if drops are required for examination, try to use unit dose vials ${ }^{3}$.

The compilation of recommendations for the management of patients requiring ophthalmological care during the SARS-CoV-2 pandemic issued by the Sociedad Mexicana de Oftalmología even includes evaluating the need to perform tonometry or postpone it at the discretion of the physician. Patients without ocular emergencies should be attended by telephone or digital applications, in addition to recommending them to wait for the health crisis to pass and to call if they have vision changes. Regarding ophthalmological surgeries, they were classified as elective if there was not a risk of visual loss in the short term, so all strabismus surgeries were categorized as such ${ }^{4}$.
With this information and with the changes that occurred in the 8 months after the health crisis started in the different countries of Latin America and the Caribbean, we designed a survey to more adequately identify the behavior and opinion of the physicians dedicated to strabismus and amblyopia, since there is a generalized concern as both conditions may be part of complex syndromes or alone they cause important neuro-visual alterations due to the delay in their diagnosis or to treatment interruption.

\section{Methods}

We prepared a questionnaire of 11 items to evaluate the impact that the pandemic may have caused on the management of strabismus and amblyopia in the different Latin American countries. The questionnaire was sent to the representatives of the Latin American countries participating in the "Visual Disability Works" carried out annually through the Mexican Center for Strabismus. The questions were written specifically to identify problems in the diagnosis and treatment of the different types of strabismus and amblyopia as a cause of visual impairment. We offered the option of safeguarding the names and information of the respondents in case they wanted to add comments. The questionnaire was applied through Google Drive and its graphic elements were used under descriptive statistics, with an exposure time from October 9 to 12, 2020. These results were partially reported on October 18, 2020 during the first fall webinar of the European Strabismological Association and the International Strabismological Association: Impact of COVID-19 on strabismus management around the world (Fig. 1).

\section{Results}

We obtained 158 responses from ophthalmologists who attend patients with strabismus and amblyopia in 14 Latin American countries as follows: Mexico 37\%, Argentina 19\%, Venezuela 14\%, Colombia 13\%, Peru 
QUESTIONNAIRE TO KNOW ABOUT THE IMPACT OF THE PANDEMIC ON THE CARE OF STRATBISMUS AND AMBLYOPIA

Considering that in Latin America Covid-19 has generated some changes in the Strabismus and Amblyopia consultation, please answer the questions and give opinions on possible alternatives to aid in ophthalmological care. (The results will be exposed globally in the ESA-ISA Webinar, without exposing the data you prefer to keep for your privacy).

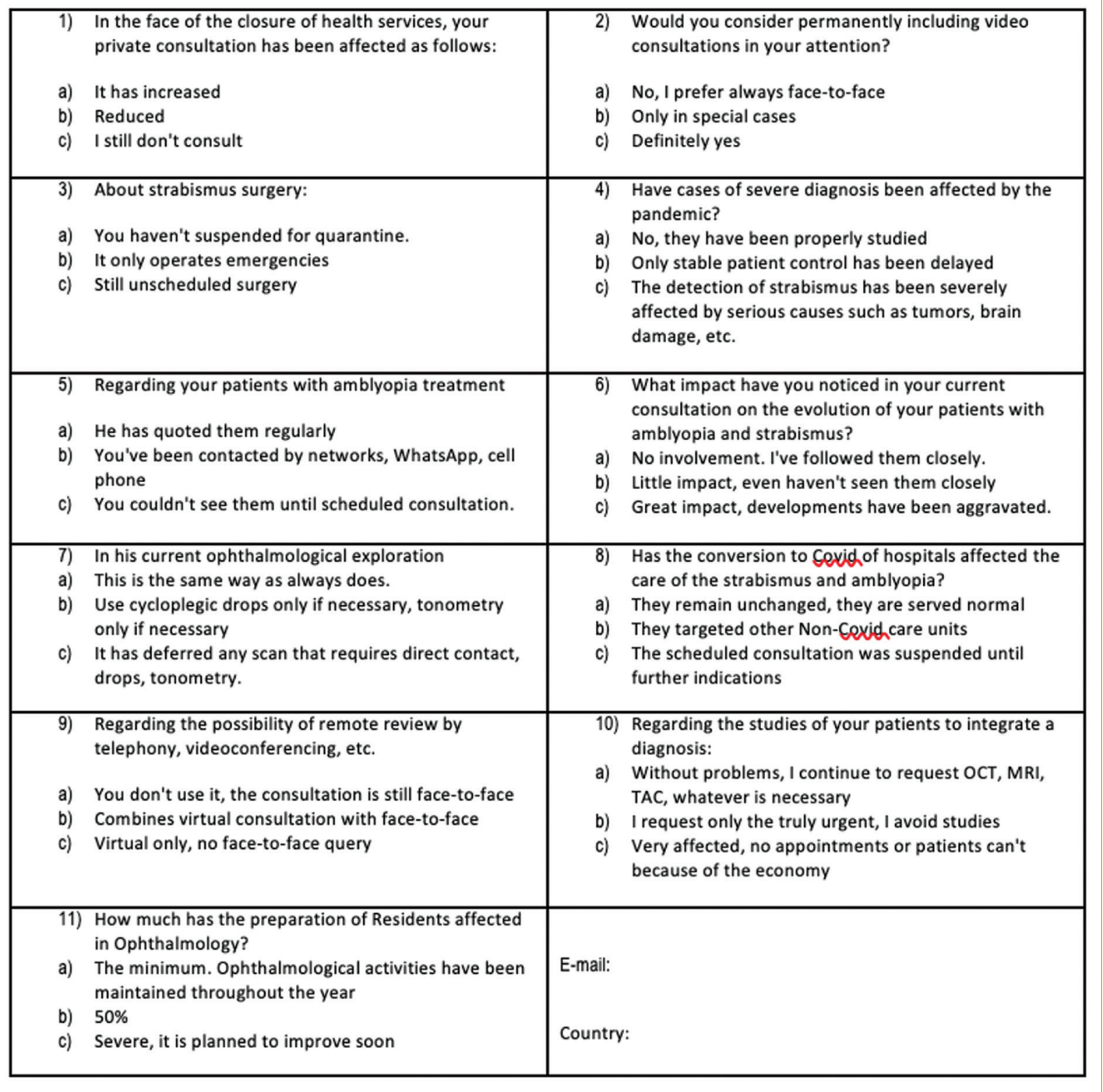

Figure 1. Questionnaire about the impact of the pandemic on strabismus and amblyopia care in Latin America.

$5 \%$, Chile $3 \%$, Ecuador $2 \%$, and Brazil, Paraguay, El Salvador, Bolivia, Costa Rica, Republic Dominican and Guatemala $1 \%$ each (Fig. 2).

Regarding question 1 (157 responses), 83.4\% considered that the private consultation has decreased, $13.4 \%$ report that it has increased and $3.2 \%$ had their consultations closed up to October 12 (Fig. 3).
In relation to question 2 (158 responses), $63.9 \%$ report using telephone consultations only in special cases, $29.1 \%$ prefer face-to-face consultations and $7 \%$ plan to stay with telephone or video consultations after the health crisis is over (Fig. 4).

Regarding question 3 (158 responses), 33.5\% have not suspended strabismus surgery due to the 


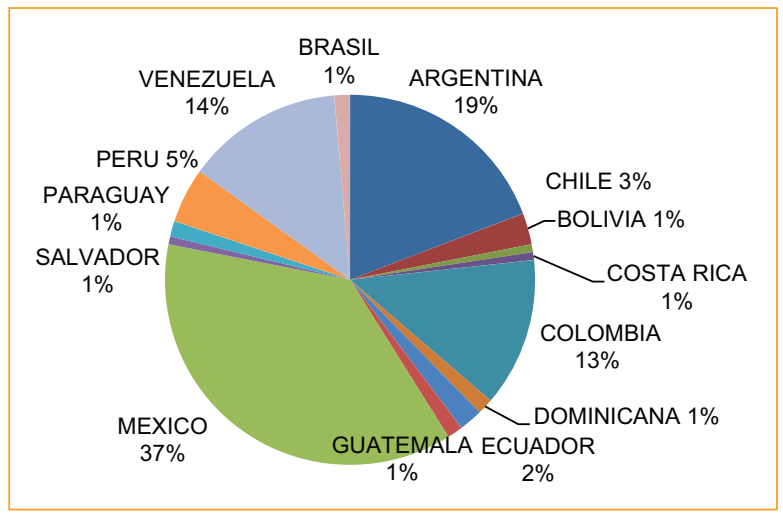

Figure 2. Participation of Latin American countries in responding the questionnaire.

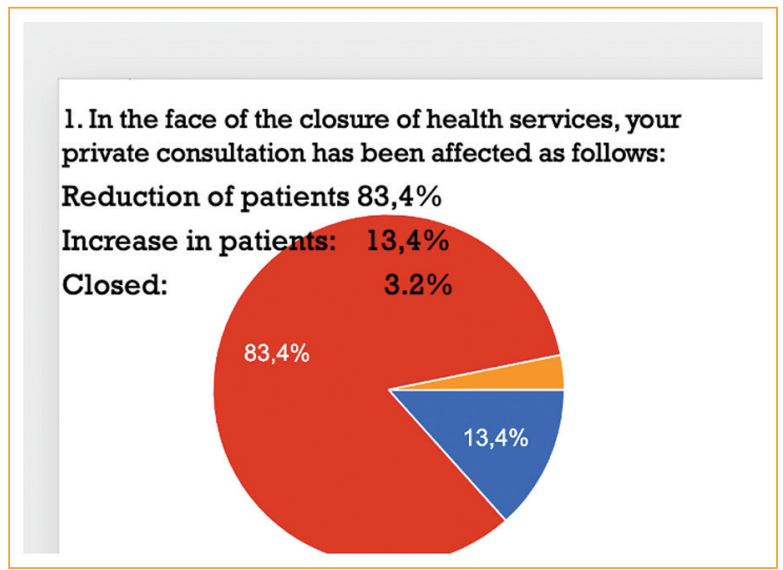

Figure 3. Consultation affectation due to the pandemic.

quarantine, $39.2 \%$ only perform surgeries in urgent cases, and $27.2 \%$ have canceled strabismus surgeries (Fig. 5).

For question 4 (157 responses), 33.1\% consider that cases of strabismus related to serious disorders have been adequately evaluated, $49 \%$ think that lack of follow-up has affected stable conditions and $17.8 \%$ consider that the detection of strabismus secondary to serious causes has been severely impaired (Fig. 6).

In question 5 (158 responses), $46.8 \%$ have not had contact with their amblyopia patients, $33.5 \%$ have been able to monitor them remotely and $19.6 \%$ have had face-to-face consultations (Fig. 7).

For question 6 (156 responses), 54.5\% consider that the impact of the pandemic on the evolution of amblyopia in their patients is low, $35.9 \%$ report a great impact
2) Would you consider permanently including video consultations in your attention?

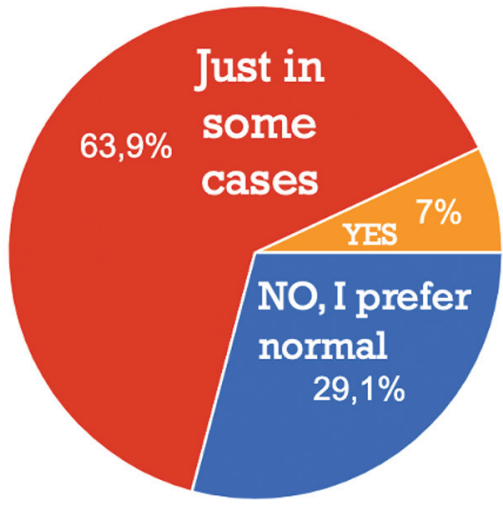

Figure 4. Permanence of video consultations.

\section{About strabismus surgery?}

Normal $\quad 33.5 \%$

\section{Emergencies only $39.2 \%$}

\section{Closed}

\section{$27.2 \%$}

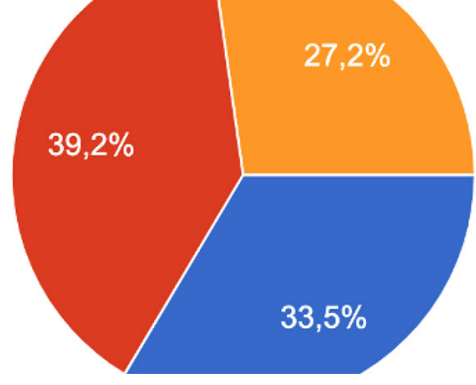

Figure 5. Strabismus surgery affectation.

with aggravation of amblyopia, and $9.6 \%$ report no changes (Fig. 8).

In question 7 (158 responses), 52.5\% report that they examine their patients as usual, without avoiding the use of eyedrops or direct contact, $45.6 \%$ mention that they use eyedrops only if it is necessary and $1.9 \%$ avoid direct contact and use of eye drops (Fig. 9).

Regarding question 8 (153 responses, non-responders are physicians not related to hospital care), $59.5 \%$ report that due to the conversion of hospitals to COVID-19, their entire scheduled consultation was suspended, $25.5 \%$ that the conversion did not affect the 


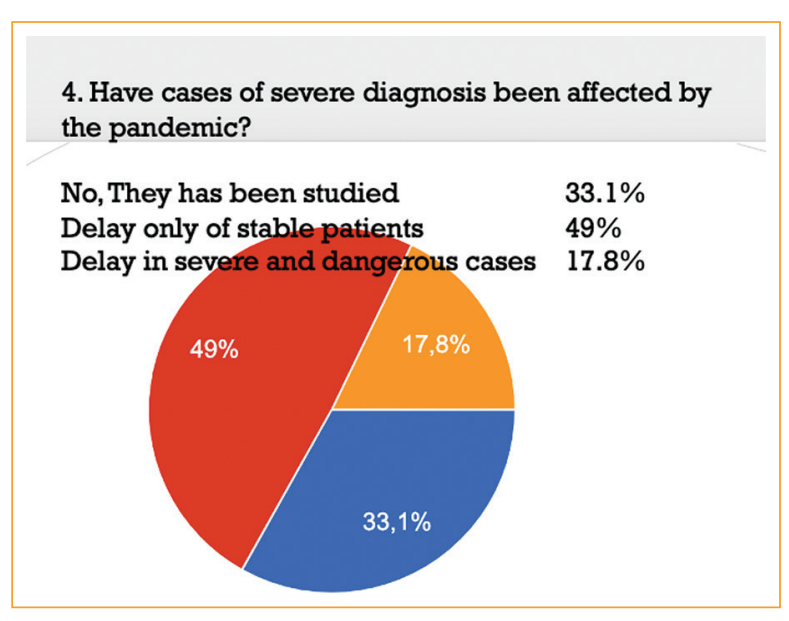

Figure 6. Effect of the pandemic in serious diagnoses.

5) Regarding your patients with amblyopia treatment He has quoted them regularly $19.6 \%$

You've been contacted by net, WhatsApp, cell phone $33.5 \%$

You couldn't see them until scheduled consultation $48.8 \%$

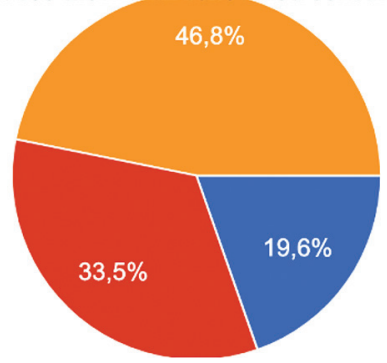

Figure 7. Type of monitoring in patients with amblyopia.

strabismus or amblyopia treatments because they went to other non-COVID-19 health units, and $15 \%$ continued their practice as usual (Fig. 10).

In question 9 (158 responses), $62 \%$ of the ophthalmologists report both teleconsultation and face-to-face consultation, $38 \%$ do not use teleconsultation (only face-to-face) and none have used teleconsultation only (Fig. 11).

Regarding question 10 (158 responses), 53.2\% continue requesting imaging or laboratory tests to their patients, $40.5 \%$ refer that they avoid requesting tests unless it is very necessary, and $6.3 \%$ responded that it has been difficult to evaluate patients due to a lack of a proper space or damage to the economy (Fig. 12).

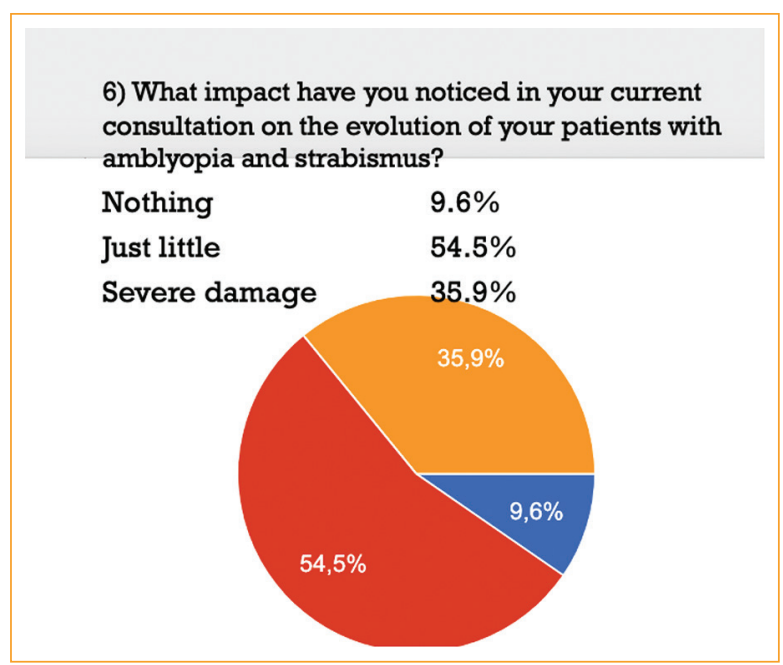

Figure 8. Effect of the pandemic on amblyopia in the absence of follow-up consultations.

\section{In his current ophthalmological exploration Same \\ $45.6 \%$ \\ Drops and Tonometry only if necessary $52.5 \%$ No drops, no Tonometry \\ $1.9 \%$}

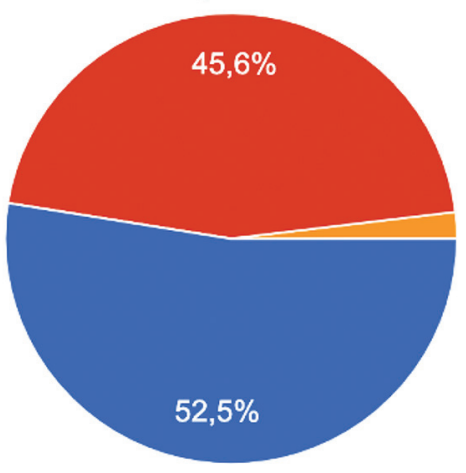

Figure 9. Changes in current examination by avoiding direct contact or the use of eyedrops.

Question 11 was added due to multiple complaints of fellow physicians who are doing a high specialty in ophthalmology in hospitals (140 responses, non-responders are physicians not related with specialty training centers). From this group, 52.1\% report a negative effect of $50 \%, 34.3 \%$ consider there is a significant negative effect that will improve later, and $13.6 \%$ consider that the negative effect has been minimal because they continue doing procedures relevant to their academic program (Fig. 13). 


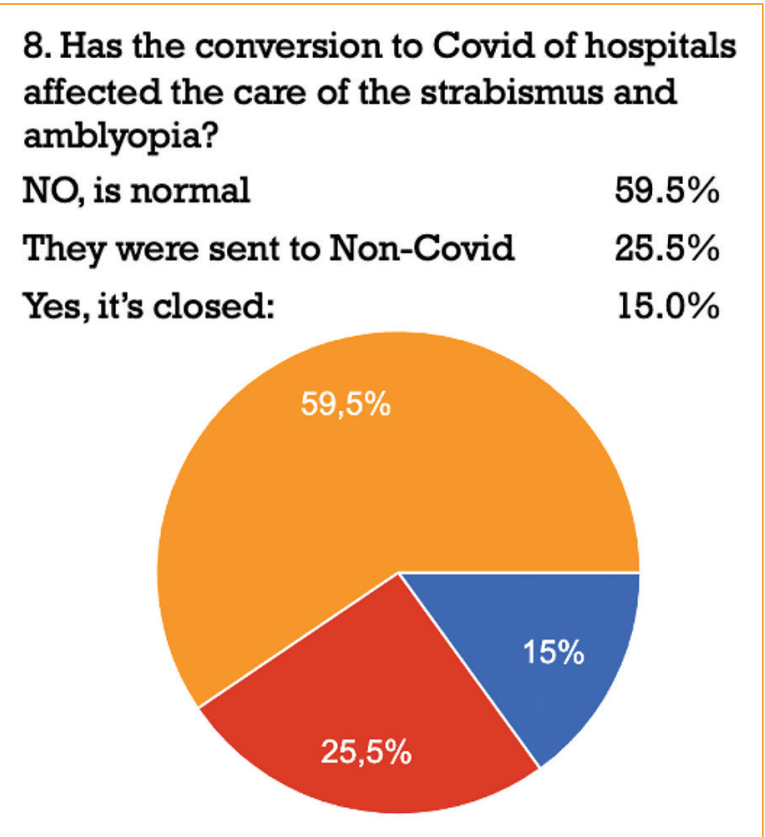

Figure 10. Consultation affectation due to hospital conversion to COVID-19.

9. Regarding the possibility of remote review
by telephony, videoconferencing, etc.
$\begin{array}{lc}\text { You don't use it } & 38 \% \\ \text { Combined } & 62 \% \\ \text { Totally virtual } & 0 \%\end{array}$

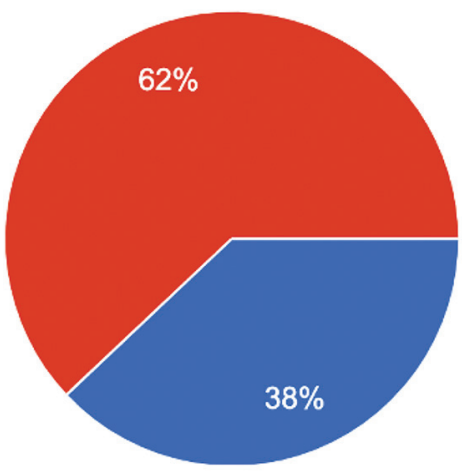

Figure 11. Current use of teleconsultations during the pandemic.

\section{Discussion}

This questionnaire makes it possible to visualize the impaired care of patients with strabismus and amblyopia, regarding both consultation and surgery, especially
10. Regarding the studies of your patients to integrate a diagnosis:

No problems, I continue to request OCT, MRI, TAC,

whatever is necessary

$53.2 \%$

I request only the truly urgent, I avoid studies $40.5 \%$

Very affected, no appointments or patients can't

because of the economy

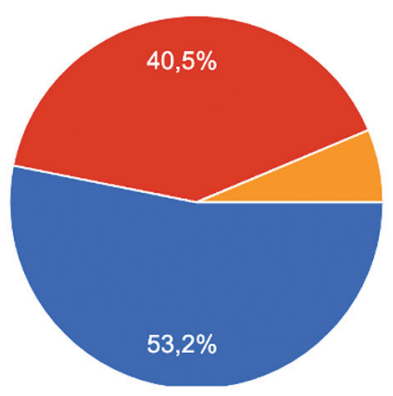

Figure 12. Affectation in the capacity of blood tests and other tests for patients.

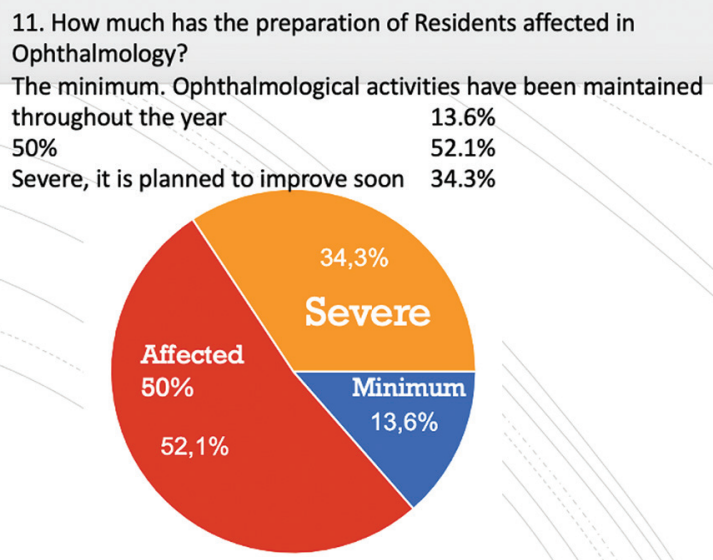

Figure 13. Impact of the pandemic in training centers for ophthalmology residents.

when it has been categorized in different clinical guidelines as "elective". Almost half of the doctors have not been able to follow up on their patients undergoing treatment for amblyopia and strabismus, and a third of them consider that the impact of the pandemic on the lack of care for these patients has been significant.

The aforementioned recommendations on reducing close examination as much as possible has led to not performing dilated fundus evaluation and tonometry, considering that they can be postponed without causing damage due to the delay. It is relevant the fear in 
the perception that cases of strabismus or nystagmus, or different causes of serious eye damage, such as tumors, serious autoimmune, inflammatory and metabolic diseases, etc., stay at home for several reasons, for example, the closing of health services, the conversion of hospitals, difficult access to imaging studies, the economic problems in the general population and very importantly, the fear of going to consultation considering that symptoms are minor without knowing the health risks related to new strabismus or relapses, paralytic strabismus, nystagmus, etc.

Ophthalmologists, to a large extent, have implemented new remote communication strategies for patient care, although a third of them do not use remote consultation, and most of those who currently use it, report that they will return to regular face-to-face consultations after the health crisis is over, and they do not pretend to perform remote consultations, even partially, in the future.

Although social networks, telephone services and videoconferences can be used in certain circumstances, a complete ophthalmological examination necessarily requires a face-to-face consultation. At the beginning of the pandemic, it seemed a viable option having remote consultations, but time has shown its difficulties. Taking into account that the duration of the health crisis has been longer than estimated at first, what seemed an acceptable and transitory option has changed due to the need of opening health services to continue with the care of patients.

The complete closure of medical services ordered by the health coordinators was one of the conditions that prompted remote care, but the absence of legal regulations in several countries for this type of remote consultation hinders its continuity.

Although telemedicine has been a means used successfully in tertiary care hospitals, it has the characteristic that on both sides there is usually a health professional presenting the patients who have already been evaluated and who can be consulted by this means for reference, monitoring or follow-up, thus facilitating their care and very frequently avoiding the mobilization of patients and the saturation of centralized health services. This type of action, as well as the electronic documents required for the case, have been adequately legislated, and so far, the authorities have determined that telemedicine is an activity integrated into clinical practice, under these conditions.

However, in many countries, including Mexico, there is still no regulation for private remote consultations, so health professionals must be subject to the principles and methods of traditional medical practice. This has motivated the revision of regulations in different countries to promote changes for the so-called teleconsultations or interactive teleconsultations, in which the contact can be from patient to doctor ${ }^{5-10}$.

However, remote consultations via telephone, teleconference, cell phone voice notes, etc., from the patient, may have certain disadvantages. For example, they may not have the necessary complete information about the professional, the possibilities of examination are quite limited in ophthalmology, this is not contemplated in the identity documents required by health laws, as in Mexico, where the patient must authorize the physical examination with his/her signature, in addition to completing the informed consent prior to care. We should also consider the risk of prescribing medications, the use of images or even the charges for this type of consultation; all of them represent a risk of malpractice. ${ }^{11-13}$

It has been suggested to inform the patient that any recommendation given remotely should be considered provisional, that it is based on what the patient is reporting and that it can never be interpreted as a medical consultation or as a diagnosis.

Regarding video conference, it should be remembered that the use of the photographs of a patient is prohibited by several laws and in any case, there must be an express authorization from the patient, in writing, authorizing the use of photographs, and the patient has the right to choose or discard those that can be published and select the time limit or mode of use of each image. Likewise, the doctor must also ask the patient to sign a discharge for the use of images and a waiver of the economic rights that the use of third-party images involves. It is worth noting that a picture of a minor or of patients who have not signed consent should never be published; for patients with disabilities, the legal representative must provide consent. Likewise, regarding the dissemination of information that has been favored by social networks, doctors must observe the law and the rules that must be followed to publish promotions, and not incur in fraudulent retention of information or misleading or false advertising, as this may entail civil and criminal liability.

It has also been insisted on not using videoconferencing in special conditions that include the following: requiring a physical examination to establish a diagnosis, if the patient has any mental health disorder that prevents him/her from giving accurate information, or if he/she has difficulties understanding the technology or the information the doctor gives ${ }^{14}$. 
There are also international warnings in countries where the use of remote consultation has already been authorized and that there is no possibility of affecting the privacy of the information if there is no control of third parties who may listen to the call, as well as the risks of recording the call, since this is not legally authorized. Physicians should only use telemedicine in countries that have jurisdictions licensed to use it, and cross-jurisdiction consultations should only be allowed between two physicians, and even ensure that their liability insurance includes the regulations relevant to teleconsultation ${ }^{15,16}$.

In Mexico, the National Commission of Medical Arbitration considers that factors involved in medical errors include, among others, a risk of poor communication between doctor and patient, poor questioning, and poor physical examination, as well as lack of follow-up, inadequate clinical history, inadequate work methods, lack of standardization of care processes, and non-compliance with standards and quality processes ${ }^{17}$.

Another aspect of great importance during the confinement forced by the pandemic has been its impact on conditions with a high risk of negative outcomes, where there has been a delay in diagnosis due to the closure of medical services and to the fear of leaving home, what we have called the "silent drama." For example, there has been a huge decrease in the number of tests for the detection of breast cancer, there has also been an impact on heart damage when staying at home (which has reached up to $200 \%$ in some regions of Italy), a decrease of $40-81 \%$ in cardiovascular tests and treatments in Spain, etc. These serious events would require a notice beyond confinement on the "stay home" warning, to raise awareness of the risks of severe diseases parallel to the pandemic ${ }^{18,19}$.

The National Population Council (Conapo) in Mexico has warned that the confinement caused by the current COVID-19 pandemic has generated an increase in unmet contraception needs of up to $20 \%$, for which there is an expectation of an additional 145,719 unwanted or unintended pregnancies in women aged 15 to 49 years, and 21,575 unwanted or unintended pregnancies in adolescents aged 15 to 19 years. Adolescent pregnancy entails a risk of prematurity that increases with the youth of the mother, with a higher rate of malformations and sequelae associated with low weight, with serious neurological damage. The premature children born in this scenario will have extremely limited facilities for rehabilitation and diagnosis, and we will probably see an increase in the number of visually and physically impaired in the following year ${ }^{20-22}$.
In addition to the frequency of visual damage, strabismus, nystagmus, neuro-visual disability, etc., in premature infants, who require immediate attention with a face-to-face examination that has been very limited during all months of confinement, there are also people with metabolic, autoimmune, endocrinological diseases, etc., which may be suffering from poor access to follow-up, medications, rehabilitation and monitoring, and diagnosis, coupled with the increase of comorbidities during confinement such as obesity, abandonment of disabled patients and even the absence of caregivers and family members ${ }^{23}$.

We understand the limitations of this analysis, considering the different opinions that stem from the conditions that exist in each country and the lack of participation of some representatives of other Latin American countries whose absence of representation in the study excludes the possibility of providing information on their current state, and we understand the inaccuracy that, despite their great value, may refer to personal opinions. The persistence in the evolution of the figures and the percentages observed during the development of the questionnaire allows us to recognize the current concerns, so we consider that this information acquires value as it is a palpable and evident situation in different health areas, which allows us to extrapolate the importance of the diagnosis of strabismus, especially those related to neurological, metabolic, and autoimmune diseases, where life may be at risk. We suggest considering opinions in the context of the population being analyzed, as well as concurrences and similarities.

\section{Conclusions}

The questionnaire on the impact of the COVID-19 pandemic demonstrates the concern of Latin American countries regarding the difficulty in monitoring patients with strabismus and amblyopia; but with greater severity in the new and silenced cases happening right now, and that the situations around confinement, economy, and difficulty of access to health services may be compromising not only visual function but life in a dangerous way.

\section{Acknowledgments}

I thank all the participants from Latin American countries for their collaboration in answering the questionnaire; as stated, names were not recorded to preserve privacy. 


\section{Conflicts of interest}

The authors declare no conflict of interests.

\section{Ethical disclosures}

Protection of human and animal subjects. The authors declare that no experiments were performed on humans or animals for this study.

Confidentiality of data. The authors declare that no patient data appear in this article.

Right to privacy and informed consent. The authors declare that no patient data appear in this article.

\section{References}

1. Gobierno de México. (Consultado el 24/10/2020.) Disponible en: https:// coronavirus.gob.mx/covid-19/.

2. STATISTA. Estado de Salud. (Consultado el 24/10/2020.) Disponible en: https://es.statista.com/estadisticas/1105121/numero-casos-covid-19-america-latina-caribe-pais/.

3. Important coronavirus updates for ophthalmologists. AAO. (Consultado el 24/10/2020.) Disponible en: https://www.aao.org/headline/alert-important-coronavirus-context.

4. Recopilación de las recomendaciones para el manejo de pacientes que requieren atención oftalmológica durante la pandemia de SARS CoV-2. (Consultado el 25/10/2020.) Disponible en: https://smo.org.mx/ archivos/documentos/2020/Recomendaciones $\% 20$ COVID-19\%20 SMO.pdf.

5. Ministerio de Salud y Protección Social. Colombia. Octubre 2019. (Consultado el 25/10/2020.) Disponible en: https://www.minsalud.gov.co/ Normatividad Nuevo/Resoluci\%C3\%B3n\%20No.\%202654\%20del\%20 2019.pdf.

6. Programa Nacional de Telesalud. Gobierno de Chile. 2015. (Consultado el 25/10/2020.) Disponible en: https://www.minsal.cl/wp-content/ uploads/2015/08/TELESALUD_webV2.pdf.

7. Ministerio de Salud y Protección Social. Colombia 2019. (Consultado el 25/10/2020.) Disponible en: https://www.minsalud.gov.co/Normatividad Nuevo/Resoluci\%C3\%B3n\%20No.\%202654\%20del\%20 2019.pdf.

8. Proyecto de Ley. Regulación de la Telemedicina en Argentina. Diputados 2020. (Consultado el 25/10/2020.) Disponible en: https://www4.hcdn.gob. ar/dependencias/dsecretaria/Periodo2020/PDF2020/TP2020/ 3142-D2020.pdf.
9. Norma Oficial Mexicana. NOM-024-SSA2-2010, que establece los objetivos funcionales y funcionalidades que deberán observar los productos de Sistemas de Expediente Clínico Electrónico para garantizar la interoperabilidad, procesamiento, interpretación, confidencialidad, seguridad y uso de estándares y catálogos de la información de los registros electrónicos en la salud. (Consultado el 25/10/2020.) Disponible en: http:// www.dof.gob.mx/normasOficiales/4151/salud/salud.htm.

10. Cámara de Diputados. Proposición para Norma Oficial Mexicana en materia de telemedicina. 21 de abril de 2020. (Consultado el 25/10/2020.) Disponible en: http://sil.gobernacion.gob.mx/Archivos/Documentos/2020/04/asun_4034093_20 200421 1587533515.pdf.

11. Reglamento de la Ley General de Salud en materia de prestación de servicios de atencón médica. Última reforma 17/07/2018. (Consultado el 25/10/2020.) Disponible en: http://www.diputados.gob.mx/LeyesBiblio/ regley/Reg LGS MPSAM 170718.

12. Norma Oficial Mexicana. NOM-004-SSA3-2012, del expediente clínico. (Consultado el 25/10/2020.) Disponible en: http://dof.gob.mx/ nota detalle popup.php?codigo $=5272787$

13. Colegio Mexicano de Ortopedia y Traumatología AC. Carta a la membresía sobre consultas a distancia. 2020. (Consultado el 25/10/2020.) Disponible en: http://www.smo.edu.mx/pdf/Opinion_Consulta Online.pdf.

14. Eguia H, Vinciarelli F, Villoslada-Muñiz RL, Sanz-García FJ. Consulta no presencial en tiempos de coronavirus: información para médicos de Atención Primaria. Medicina de Familia. SEMERGEN. Digital 23/10/2020. (Consultado el 25/10/2020.) Disponible en: https://www.elsevier.es/es-revista-medicina-familia-semergen-40-avance-resumen-consulta-no-presencial-tiempos-coronavirus-S1138359320303129?newsletter=true\&coronavirus.

15. Declaración de la AMM sobre la ética de la telemedicina. Julio 2, 2020. (Consultado el 25/10/2020.) Disponible en: https://www.wma.net/es/policies-post/declaracion-de-la-amm-sobre-la-etica-de-la-telemedicina/.

16. Inspectorate $\mathrm{C}$. Information pack for video consulting in care home. Versión 2, 2019. (Consultado el 25/10/2020.) Disponible en: https://hub. careinspectorate.com/media/3633/care-home-resource-pack.pdf.

17. Boletín CONAMED- OPS. Abril 2016. El acto médico. Error y la mal praxis. (Consultado el 25/10/2020.) Disponible en: http://www.conamed. gob.mx/gobmx/boletin/pdf/boletin5/acto_medico.pdf.

18. Luna-Tomás MA, Margelí-Vila M, Ríos-Gozálvez C. Influencia de la pandemia por enfermedad por coronavirus 2019 en el manejo del cáncer de mama. Clin Invest Ginecol Obstet. 2020;47:89-90.

19. Moguel R, Samaniego V, Cabrera C, Chacek S, Estrada A. Missing heart attacks during confinement. Cardiovasc Metab Sci. 2020;31:38-9.

20. Los efectos de la pandemia del COVID-19: desafíos para la salud sexual y reproductiva. (Consultado el 25/10/2020.) Disponible en: https://www. gob. $\mathrm{mx} / \mathrm{conapo/articulos/participa-conapo-en-dialogo-virtual-so-}$ bre-los-efectos-de-la-pandemia-del-covid-19-desafios-para-la-salud-sexual-y-reproductiva?idiom=es.

21. Vavouraki $E$. The impact of COVID-19 pandemic on the healthcare of premature babies. Eur J Midwifery. 2020;4(May). doi:10.18332/ejm/122385

22. Vallejo-Barón J. Embarazo en adolescentes, complicaciones. Rev Med Costa Rica y Centroamerica. 2013;70:65-9.

23. Moguel-Ancheita S, Orozco-Gomez LP. Analysis of risk factors for neurodevelopment and visual functions in the preterm infant to establish an early detection and treatment. Arch Ophthalmol Eye Disord. 2020;2:10-9. 